\title{
THE REGULATION OF THE OFFENCES AGAINST THE CORPORAL INTEGRITY AND HEALTH IN THE NEW CRIMINAL CODE
}

\section{C. Șerban Morăreanu, D. Crețu}

\section{Camelia Șerban Morăreanu}

Associate Prof. PhD - University of Piteşti, Faculty of Law and Administrative Sciences, (Romania),

*Correspondence: Camelia Şerban Morăreanu, University of Piteşti, str. Târgul din vale, No.

1, Piteşti, Argeş, România

e-mail: cameliamorareanu@yahoo.com

\section{Daniel Crețu}

Prosecutor's Office attached to Costeşti City Court,

*Correspondence: Daniel Crețu, Costeşti Court Prosecutor's Office, Str. Victoriei No. 72, Costeşti, Argeş, România

e-mail:danielcretu2003@yahoo.com

\section{Abstract}

The incriminations made by Section II of Chapter 1 of Title II of the actual Code (section titled "Hitting and damage to corporal integrity or to health")"are found in the Special Part of the New Criminal Code", in Chapter II of Title 1, chapter titled "Offences against life, corporal integrity or health". This chapter maintains the offences of "Hitting or other violence" and "Bodily harm". These two offences include the consequences of the serious bodily harm - offence which disappears from the new regulation. Beside the two offences, are maintained in the new structure: "Hitting or injury causing death" and "Bodily harm by negligence". Are added within this chapter "Ill treatment applied to minors" (in the actual regulation this offence is stated by Art 306) and "Scuffle" (in the actual regulation this offence is stated by Art 322).

The new Criminal Code incriminates in the same conditions hitting or injuries causing death $^{2}$. The only difference is given by the limits of the punishments, which are smaller, in accordance with a new logic of the punishments residing from the entire economy of the new Code. But even regarding these offences must be given the necessary procedural warranties regulated by the new Code of Criminal Procedure ${ }^{3}$ or by different international documents, to which Romania is part ${ }^{4}$.

Key words: offence, violence, new Criminal Code, new Code of Criminal Procedure

\footnotetext{
${ }^{1}$ Law No 286/2009, with subsequent modifications and amendments.

2 Art 195 "Hitting or injury causing death" states that "Should one of the acts in Art 193 and 194 result in the victim's death, the penalty shall be imprisonment from 6 to 12 years".

${ }^{3}$ Law No 135/2010, with subsequent modifications and amendments

${ }^{4}$ L.M Trocan, Garantarea dreptului la apărare în lumina dispozițiilor tratatelor internaţionale specializate $\hat{\imath}$ materia drepturilor omului şi jurisprudenței CEDO, the Annals of the "Constantin Brâncuşi" University of Târgu-Jiu, Legal Sciences Series, No 4/2010, pp.111-128 (http://www.utgjiu.ro/revista/jur/pdf/20104/8_LAURA_MAGDALENA_TROCAN.pdf)
} 


\section{Hitting or other forms of violence ${ }^{5}$ and bodily harm $^{6}$ - the differences to the current regulation}

The new Criminal Code brings a simplification in the area of offences against corporal integrity or health, regrouping the offences incriminated by Art 180, 181 and 182 of the actual Code in just two offences, namely: hitting or other forms of violence, stated by Art 193 of the new Code and bodily harm, stated by Art 194 of the new Code.

Hitting or other forms of violence is found as name in the new Criminal Code, but the incrimination has a wider area of application regarding the immediate consequences.

The new Criminal Code maintains as marginal name the offence of bodily harm, in Art 194, but the content of the offence is modified, meaning that are taken some of the consequences stated by the actual Code to the offence of serious bodily harm.

The acts of violence committed against family members, which in the actual regulation appear as agreed versions of the offences of hitting or other forms of violence and bodily harm, appear as a different offence, having as marginal name family violence, stated by Art 199.

The new Criminal Code no longer states an incrimination named serious bodily harm, but we found some of the consequences of this offence in the other two incriminations left: hitting or other forms of violence and bodily harm.

The criterion for the distinction between these two offences is double, namely the duration of the medical care needed and the nature of the injuries caused, but with some differences. Regarding the number of days for medical care, it has renounced to a detailed differentiation based on a smaller number of days, keeping a single criterion, namely that of 90 days. If the offence caused only physical sufferance, is shall be incriminated according to Art 193 Para 1, if the offence affected a person's health or caused traumas with a seriousness evaluated at 90 days, it shall be incriminated according to Art 193 Para 2, and if it caused traumas that needed more than 90 days of medical care, it shall be incriminated according to Art 194 Para 1 Let b).

Also Art 194 incriminates the consequences related to the second criterion, namely the nature of the traumas. From this perspective, we note that it preserves only the hypothesis of infirmity, to the idea that includes the loss of a sense or organ and the cessation of its function. The term "ugly" is replaced with the term "serious and permanent esthetic damage", used both by the doctrine, as well as in practice.

Unlike the old text of serious bodily harm, the aggravated form of the offence of bodily harm of the new Criminal Code, committed with direct intention (Art 194 Para 2) is made a correct reference to only the first three consequences stated for the normal offence [Art 194 Para 1 Let a), b) and c)].

\footnotetext{
${ }^{5}$ Art 193 of the new Criminal Code titled "Hitting or other forms of violence" state: (1) Hitting or any other act of violence causing physical suffering shall be punished by imprisonment from 3 months to 2 years or by fine; (2) Hitting or acts of violence that caused an injury needing medical care of up to 90 days shall be punished by imprisonment from 6 months to 5 years or by fine; (3) Criminal action is initiated upon prior complaint of the injured person.

6 Art 194 of the new Criminal Code titled "Bodily harm" states: (1) The offence stated by Art 193 causing one of the following consequences shall be punished by imprisonment from 2 to 7 years:

An infirmity;

Traumatic lesions or affected the health of a person, needing medical care of more than 90 days;

A permanent and serious esthetic harm;

Abortion;

Jeopardized the life of the person.

(2) When the offence was committed with the purpose of producing one of the consequences stated by Para 1 Let a), b) and c), shall be punished by imprisonment from 3 to 10 years; (3) The attempt to the offence stated by Para 2 is punished.
} 
If, the purpose for which the offender acted was to produce an abortion, it shall be considered a plurality of offences between bodily harm and one of the offences stated by Chapter IV Title I of the Special Part, titled "Offences against the fetus", namely the termination of pregnancy ${ }^{7}$ and violence against the fetus ${ }^{8}$.

If the purpose for which the offender acted was to endanger the life of the person, it shall be considered as attempt of murder ${ }^{9}$.

\section{Bodily harm by negligence ${ }^{10}$ - differences from the actual regulation}

This offence is restructured in agreement with the new configuration of the offences of hitting and other violence and bodily harm. It is noticed a simplification of the regulation, in accordance with the one made for the offence of homicide out of negligence.

An aggravated form was included, for the case in which two or more persons have been injured. Thus it was removed the inconsistency from the actual Criminal Code, which states as a single offence the case in which two or more persons have been killed out of negligence ${ }^{11}$ and a plurality of offences when they have only been harmed. Maintaining this inconsistency could have led to a more severe punishment for the author of the harm by negligence of more persons (as an effect of maintaining the plurality of offences) unlike the situation of the author of a homicide out of negligence committed in similar circumstances.

\section{Ill treatment applied to minors ${ }^{12}$ and scuffle ${ }^{13}$}

In this chapter are added two offences, which in the actual regulation are stated in another title, namely Title IX Offences that infringe upon relations that concern social community life, Art 306 and 322.

Bringing these two offences in this category is motivated by their legal object, namely the fact that, really, the offences incriminated prejudice, firstly the physical integrity or the health of the person, and in subsidiary, the family relations or relations that concern social community life.

\footnotetext{
${ }^{7}$ Art 201 of the new Criminal Code

${ }^{8}$ Art 202 of the new Criminal Code

${ }^{9}$ Stated by Art 188 and 189 of the new Criminal Code

${ }^{10}$ Art 196 of the new Criminal Code titled "Bodily harm by negligence" states: (1) Acts provided in Art 193 Para 2 committed by a person under the influence of alcohol or a psychoactive substance or in the performance of an activity representing an offence shall be punished by imprisonment from 3 months to one year or by fine; (2) The offence stated by Art 194 Para 1 committed by negligence shall be punished by imprisonment from 6 months to 2 years or a fine; (3) When commission of the act in Para 2 is the result of non-abidance by legal provisions or precaution measures for the exercise of a profession or trade, or for the accomplishment of a certain activity, the penalty shall be imprisonment from 6 months to 3 years or a fine; (4) Should the acts in Para 1-3 are committed by two or more persons the special limits are incremented by one third; (5) For the non-abidance of the legal provisions or precaution measures or the accomplishment of the activity which led to the commission of the acts stated by Para 1 and 3 is by itself an offence, shall be applied the rules of the plurality of offences; (6) The criminal action shall be initiated upon the prior complaint of the injured person.

${ }^{11}$ We hereby reiterate the provisions incriminating the offence of homicide out of negligence - namely Art 178 Para 5 of the actual Criminal Code, stating that "If the act committed caused the death of two or more persons, the maximum of the penalties in the previous paragraphs can be supplemented by an increase of up to 3 years". Such provision is not found in Art 184 of the actual Criminal Code stating the offence of bodily harm by negligence.

${ }^{12}$ Art 197 of the new Criminal Code titled "Ill treatment applied to minors" states: "The act of seriously jeopardizing, either by measures or treatments of any kind, a minor's physical, intellectual or moral development, committed by the parents or by any person entrusted with the minor for raising and education, shall be punished by imprisonment from 3 to 7 years and the prohibition of certain rights".

${ }^{13}$ Art 198 of the new Criminal Code titled "Scuffle" states: (1) Participation to a scuffle between several persons shall be punished by imprisonment from 3 month to one year or by fine; (2) If the scuffle caused any serious injury upon a person's corporal integrity or health and it is not known which of the participants committed the acts, the penalty of imprisonment from 1 to 5 years shall be applied to all of them, except to the injured person, who shall be held liable according to Para 1; (3) In case that death of a person was caused, the special limits of the penalty shall be incremented by a third; (4) A person who has been caught in a scuffle against his will, or who tried to separate others, to reject an attack or to defend another person, shall not be punished.
} 
Besides, regarding the offence of ill treatment applied to minors, it has never been considered an offence with a special active subject. It can be committed not only by a family member or against a family member, but also against minors institutionalized in placement centers or in other forms of child protection centers, by the persons who must care for them.

It is noticed also the fact that in other legislations the offence of ill treatment applied to minors appears in the same shape or in a similar one, in the category of offences against corporal integrity or health ${ }^{14}$.

Numerous legislations also state the scuffle in the category of offences against corporal integrity ${ }^{15}$. It is noticed the fact that it is maintained the exoneration from criminal liability of the person who is caught in a scuffle against his will or who tried to separate the others.

The differentiations from the actual regulation regard the limits of the punishment, which are considerably lower than in the actual Criminal Code.

\section{Procedural provisions on the offences against corporal integrity or health}

From the five offences representing the content of the chapter regarding the offences against corporal integrity or health, only for the offences of hitting or other forms of violence, stated by Art 193 of the new Criminal Code and bodily harm by negligence, stated by Art 196 of the new Criminal Code, the criminal action is initiated at the prior complaint of the victim.

This means that, according to Art 111 of the new Code of Criminal Procedure, at the beginning of the first hearing, the victim is notified (besides another series of rights) of the fact that she has the right to file prior complaint against the person she holds responsible.

If one of the offences is flagrant, the criminal investigation organ is compelled to establish its commission even in the absence of a prior complaint, but subsequently it shall summon the victim, and if she agrees to file a prior complaint, shall initiate the criminal investigation. Otherwise, the criminal investigation organ shall submit the case file to the prosecutor proposing the classification ${ }^{16}$.

If, for any of the two offences, the prior complaint of the victim is missing, the criminal action cannot be initiated. Also, if the victim, after submitting such a complaint, withdraws it, the initiated criminal investigation can no longer be continued ${ }^{17}$. In this latter case, the victim shall support the judicial expenses caused to the state ${ }^{18}$.

An important modification brought by the new Code of Criminal Procedure in the area of the prior complaint regards the term in which it can be submitted. Thus, it must be submitted within three months from the day the victim learned about the offence, with the mention that if the victim is a minor or an incapable, the three months term shall begin from the moment when his legal representative (or new legal representative, if he has been replaced) learned about the offence ${ }^{19}$.

All the other provisions contained by the actual Code of Criminal Procedure in the area of the prior complaint are maintained by the new Code of Criminal Procedure.

\section{Bibliography}

Law No 286/2009 regarding the Criminal Code, with modifications and amendments inserted by Law No 27/2012, Law No 63/2012 and Law No 187/2012;

Law No 135/2010 regarding the Code of Criminal Procedure, with modifications and amendments inserted by Law 63/2012 and Law No 255/2013;

\footnotetext{
${ }^{14}$ Art 152 of the Portuguese Criminal Code, Art 225 of the German Criminal Code, Art 92-93 of the Austrian Criminal Code.

${ }^{15}$ Art 231 of the German Criminal Code, Art 91 of the Austrian Criminal Code, Art 154 of the Spanish Criminal Code, Art 151 of the Portuguese Criminal Code, Art 133 of the Swiss Criminal Code.

${ }^{16}$ Art 298 of the new Code of Criminal Procedure.

${ }^{17}$ Art 16 of the new Code of Criminal Procedure.

${ }^{18}$ Art 275 Para 1 Point 2) Let b) of the new Code of Criminal Procedure.

${ }^{19}$ Art 296 of the new Code of Criminal Procedure.
} 
L. M. Trocan, Garantarea dreptului la apărare în lumina dispozițiilor tratatelor internaționale specializate în materia drepturilor omului şi jurisprudenței CEDO, the Annals of the "Constantin Brâncuşi” University of Târgu-Jiu, Legal Sciences Series, No 4/2010; 